\title{
Variability and Main Controlling Factors of Hydrocarbon Migration and Accumulation in the Lower Paleozoic Carbonate Rocks of the Tazhong Uplift, the Tarim Basin, Northwest China
}

\author{
Qifei Fang $\mathbb{D},{ }^{1,2}$ Qingzhou Yao, ${ }^{2}$ Yongqiang $Q u\left(\mathbb{D},,^{2}\right.$ Youlu Jiang $\mathbb{D},{ }^{1}$ Huizhen $\mathrm{Li}^{2}$ \\ Dongdong Dai, ${ }^{2}$ Shan Fan, ${ }^{3}$ Weiping Zhu, ${ }^{2}$ Lisha Yang, ${ }^{2}$ Xiaoxue Wang, ${ }^{3}$ and Min Zhang $^{3}$ \\ ${ }^{1}$ School of Geosciences, China University of Petroleum (East China), Qingdao 266580, China \\ ${ }^{2}$ Research Institute of Petroleum Exploration \& Development-Northwest, Lanzhou 730020, China \\ ${ }^{3}$ PetroChina Tarim Oilfield Company, Korla 841000, China \\ Correspondence should be addressed to Qifei Fang; qffang@petrochina.com.cn
}

Received 17 December 2020; Revised 11 May 2021; Accepted 5 August 2021; Published 25 August 2021

Academic Editor: Jianhui Yang

Copyright (C) 2021 Qifei Fang et al. This is an open access article distributed under the Creative Commons Attribution License, which permits unrestricted use, distribution, and reproduction in any medium, provided the original work is properly cited.

\begin{abstract}
Hydrocarbon migration patterns and pathways were studied on the basis of three-dimensional seismic interpretation, drilling, geochemistry, production performance, and other data. Using these findings, the main factors controlling hydrocarbon migration and accumulation in the Lower Paleozoic carbonate rocks of the Tazhong Uplift were discussed. The spatiotemporal relationship between the hydrocarbon kitchens and pathway systems of the Tazhong Uplift and the spatial pattern of pathway systems were considered the main factors causing differences in hydrocarbon enrichment. Results also revealed that the Lower Paleozoic carbonates of the Tazhong Uplift have two hydrocarbon accumulation systems (inside and outside the source rocks). For the accumulation system within the source rocks, hydrocarbon migration and enrichment are vertically differentiated. Middle Cambrian gypsum salt rocks serve as the boundary, above which thrust and strike-slip faults mainly allow vertical transport of hydrocarbons. A multistage superposition pattern of strike-slip faults controls the differences in hydrocarbon enrichment on the periphery of the fault zone. Beneath the gypsum-salt rocks, hydrocarbon migration and enrichment is controlled by the topography of paleostructures and paleogeomorphology. For the hydrocarbon accumulation system outside the source rocks, hydrocarbon migration and enrichment are restricted by the layered pathway system, and the topography of the paleostructures and paleogeomorphology is the key factor controlling hydrocarbon enrichment. The Tazhong No. 1 Fault is the main vertical pathway system in the area underlain by no source rocks, and hydrocarbons are enriched at the periphery of the Middle-Lower Cambrian and No. 1 Fault Zone.
\end{abstract}

\section{Introduction}

The ultradeep ancient carbonate rocks of the Tarim Basin, with an abundance of hydrocarbon resources, are an important field with the best exploration prospects [1,2]. Discovery of a series of large carbonate oil and gas fields, such as the Tazhong No. 1 Gas Field and Tazhong Block III Oil Field demonstrated that the Lower Paleozoic carbonate reservoirs of the Tazhong Uplift contain rich oil and gas resources. However, the complexity of its hydrocarbon distribution severely limits exploration and development progress. Here, the deep carbonate rocks present physical properties clearly different from those of clastic rocks. The average matrix porosity is less than $2 \%$, permeability is less than $5 \times 10^{-3}$ $\mu \mathrm{m}^{2}[3,4]$, and the compactness and high heterogeneity greatly impair the free flow of oil and gas. In these rocks, pathway elements occur as faults, fractures, and unconformity surfaces. Secondary dissolved pores participate in modifying the rock properties, enhancing reservoir porosity and permeability, and providing the necessary conditions for hydrocarbon migration, adjustment and accumulation in carbonate rocks $[5,6]$.

Research on the main controlling factors of hydrocarbon accumulation in the carbonate rocks of the Tazhong Uplift 


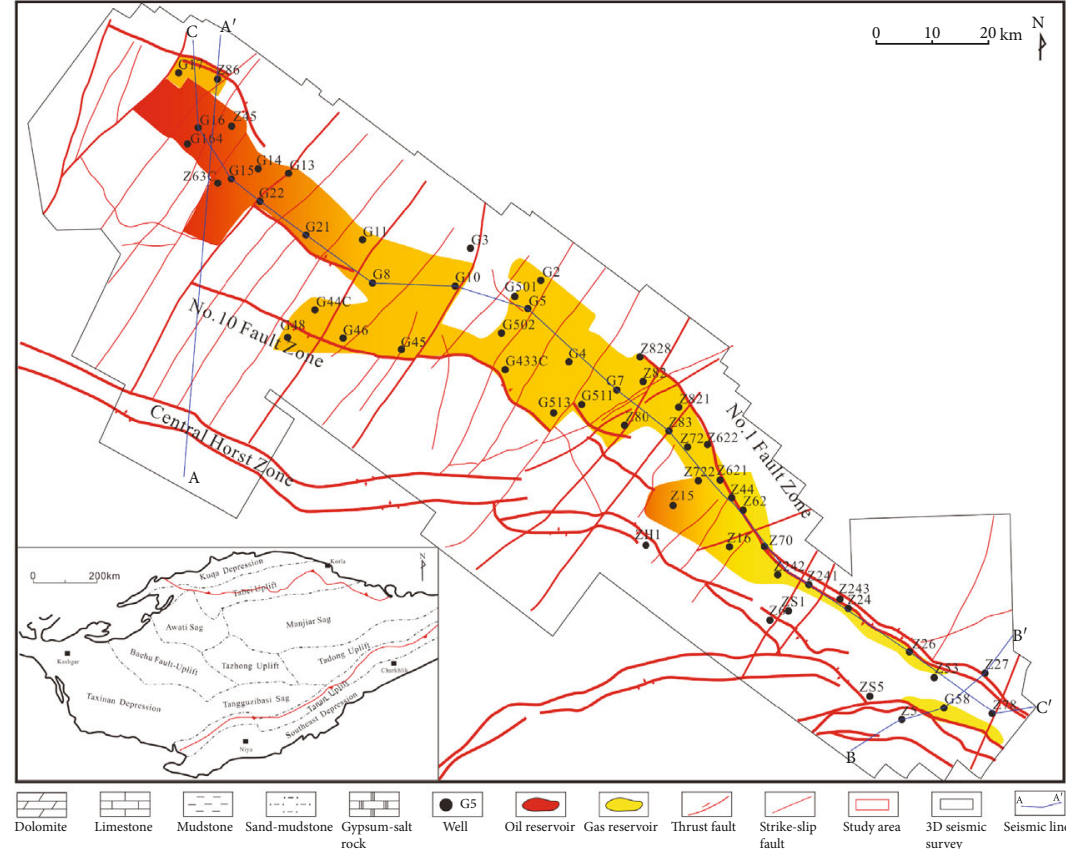

(a)

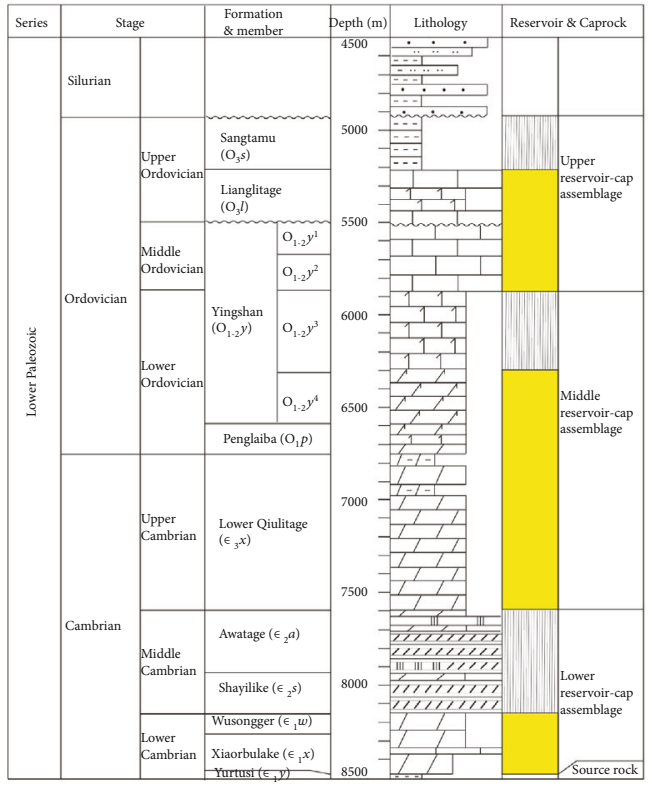

(b)

FIgURE 1: Structures and stratigraphy of the Tazhong Uplift. (a) The regional structures and the distribution of the petroliferous zone across the top of the carbonate rocks of the Tazhong Uplift, showing the abundance of oil (in the west) and gas (in the east), and convergence of the distribution from west to east. (b) The Lower Paleozoic stratigraphic column, showing that the Cambrian-Ordovician carbonate rocks form three reservoir-cap assemblages (upper, middle, and lower) typical of the type and contact relations of reservoir and cap rocks. Following the convention of the PetroChina Tarim Oilfield Company, which divides the Cambrian System into three series, this paper adopts the terms Lower, Middle, and Upper Cambrian Series.

has gradually shifted attention away from the initial search for favorable reservoirs and towards hydrocarbon pathway systems. By analyzing pathway systems such as faults and unconformity surfaces in the carbonate rocks of the Tazhong Uplift, past studies have summarized the structural style of the pathway framework and its control on hydrocarbons. In particular, they demonstrated the important role of faults on hydrocarbon accumulation in carbonate rocks, which helped guide oil field exploration in the early stages [7-11]. With advances in exploration techniques, focusing solely on the structural controls of a single pathway system on hydrocarbon flow direction and rate will impair decision-making and deployment of oil and gas exploration.

By analyzing the temporal-spatial coupling between different pathway systems and the main hydrocarbon source rocks in the Tazhong Uplift, this paper explores the hydrocarbon migration and enrichment characteristics of carbonate rocks under the control of various pathway systems and identifies favorable zones for hydrocarbon accumulation. This study will provide a reference for oil and gas exploration, and for development of deep carbonate oil and gas reservoirs in superimposed basins, enabling in-depth investigation of the patterns of hydrocarbon migration in carbonate rocks.

\section{Geological Setting}

The Tazhong Uplift is located in the center of the Tarim Basin. It is sandwiched between the Manjiar Sag and the
Tangguzibasi Sag, on the west of the Tadong Low Uplift and to the east of the Bachu Fault (Block)-Uplift (Figure 1). As a typical inherited paleouplift structure that has experienced multicycle tectonic sedimentary evolution, the Tazhong Uplift has undergone tectonic evolution stages such as the Middle-Late Caledonian period, the Late HercynianIndosinian period, and the Himalayan period $[12,13]$. These multiple events have had significant influences on hydrocarbon migration, accumulation, adjustment, preservation, and spatial distribution [14]. During the Middle-Late Caledonian period, NW thrust fault zones formed due to the compression of the active continental margins of the basin to the south and north. These include the No. 1 Fault Zone, the Central Horst Zone, and No. 10 Fault Zone. Some of the thrust fault zones are absent from the Middle-Upper Ordovician Series and the Silurian-Devonian Systems, or from the large-scale unconformity developing at the top of the Middle-Lower Ordovician. During the Late HercynianIndosinian period, the Tarim Basin evolved towards a retroarc foreland basin, and the NE-striking strike-slip fault zones of the Tazhong Uplift further developed. During the Himalayan period, the basin was affected by the collision of the Indian and Eurasian continental plates and the Altyn Tagh strike-slip faulting; therefore, parts of the early-formed strike-slip faults of the Tazhong Uplift were reactivated.

The Cambrian-Ordovician System of the Tazhong Uplift is a carbonate rock deposit (Figure 1(b)). Above the Cambrian-Ordovician System is the Silurian System of 
sand-mudstone deposits, which is not the focus of this paper. The Cambrian-Ordovician System is a set of openrestricted marine deposits, wherein the Cambrian strata are relatively well developed. At the base of the Lower Cambrian Series is the Yurtusi Formation $\left(\epsilon_{1} y\right)$ mudstone, overlain by the Xiaorbulake Formation $\left(\epsilon_{1} x\right)$ dolomite. The Middle Cambrian Series is composed of thick gypsum-salt rock, and the Upper Cambrian Series is thick dolomite. The Ordovician System, currently the focus of oil and gas exploration and development of deep carbonate rocks, consists (from bottom to top) of the Penglaiba Formation $\left(\mathrm{O}_{1} p\right)$ dolomite, the Yingshan Formation $\left(\mathrm{O}_{1-2} y\right)$ limestone and the Yijianfang Formation $\left(\mathrm{O}_{2} y\right)$ limestone, the Lianglitage Formation $\left(\mathrm{O}_{3} l\right)$ reef-flat limestone, and the Sangtamu Formation $\left(\mathrm{O}_{3} \mathrm{~s}\right)$ mudstone. The primary pores of the CambrianOrdovician carbonate rock reservoirs of the Tazhong Uplift have almost disappeared. Secondary karst fracture cavity systems have developed due to the effects of weathering crusts, interlayer karst, and fractures, to form a typical quasilayered karst fracture cavity reservoir. The superhick gypsum salt rock of the Middle Cambrian Series, the tight marl of the 3rd and 4th members of the Yingshan Formation, and the superthick mudstone of the Sangtamu Formation, comprise three regional caprocks with stable distribution. Therefore, the Cambrian-Ordovician System includes three reservoir-cap assemblages (upper, middle, and lower) typical of the contact relations between the reservoir and cap rocks. The upper reservoir cap assemblage is from the Sangtamu Formation to the 2nd member of the Yingshan Formation, the middle reservoir cap assemblage is from the 3rd member of the Yingshan Formation to the Upper Cambrian Series, and the lower reservoir cap assemblage is the Middle-Lower Cambrian Series.

\section{Results}

\subsection{Fault Characteristics}

3.1.1. Characteristics of Strike-Slip Fault. Two types of faults, thrust faults and strike-slip faults, have developed together in the Tazhong Uplift. The faults have become increasingly important for hydrocarbon transport in the carbonate rocks and are an essential feature when studying hydrocarbon accumulation. The focus of recent research has shifted from the original Tazhong No. 1 thrust Fault Zone to the strike-slip fault. Some studies have even proposed that the strike-slip faults of the Tazhong Uplift are the main factor controlling the migration and accumulation of most hydrocarbons. It has been suggested that a general exploration of the strike-slip fault zone is required [15].

The Tazhong Uplift has developed two strike-slip fault groups in different directions. One group is NE-SW, which is the main strike-slip fault of the Tazhong Uplift; the other group is in the NEE-SWW direction, containing several strike-slip faults confined to the central region of the Tazhong Uplift.

Taking the strike-slip faults on the top of the Ordovician carbonate rocks as an example, the strike-slip faults have a north-south segmented tectonic style and are divided into linear, braided, diagonal, and ponytail segments (Figure 2). Generally speaking, the strike-slip faults in the south are mainly linear strike-slip faults, and the faults are upright in profile; the strike-slip faults in the north are divergent in the stress release areas such as the thrust tectonic belt and No. 1 Fault Zone, featuring diagonal or ponytail patterns. Their overall planar distribution is characterized by southnorth zoning. The southern fault zone is strongly compressed, forming a straight and closed linear strike-slip segment, which gradually changes to tensile stress towards the north. The tectonic style of the fault plane changes to diagonal, braided, or ponytail patterns, and the tectonic style of the profile changes from plate-like to a positive or negative flower-like pattern. The stress transition zone of the strike-slip fault tends to form an extensional or compressive bending belt. The strata within the bending belt are strongly fragmented, greatly increasing the fluid transport capacity in both horizontal and vertical directions [16].

The actions of compressive and tensile stresses in the strike-slip faults, and differences in the degree of fragmentation of fault zones, have caused significant differences between individual fault zone segments, in terms of the width and intensity of damage. In a straight and tightly closed linear strike-slip segment, the activity of the strikeslip fault zone gradually declines from deep to shallow [17]. Meanwhile, the braided, diagonal, and horsetail strike-slip segments and other extensional or compressive bending faults show more damaged fault zones and increasing activity from deep to shallow. According to the statistics of emptying and lost circulation obtained during drilling and imaging logging, the proportion of dissolved cavities (above $0.1 \mathrm{~m}$ ) around the fault zone is more than $75 \%$ [18].

3.1.2. Characteristics of Thrust Fault. Once strike-slip faults had become the main research objective for studies of hydrocarbon accumulation in the carbonate rocks of the Tazhong Uplift, the role of thrust faults on hydrocarbon transport was generally ignored. Thrust faults are mostly distributed in the NW-SE direction, with a brush structure that is broad in the northwest and converges towards the southeast. Development of the Central Horst Zone is relatively complete, and the No. 1 and No. 10 Fault Zones have developed a mutual pattern. That is, in the area where the No. 10 Fault Zone develops, the No. 1 Fault Zone disappears at the corresponding subparallel position, and fault displacement of the No. 1 Fault Zone in the north is obvious where the No. 10 Fault Zone is extinct. With respect to the stress mechanism, compressive stress applied from the south encounters obstacles is adjusted by strike-slip faults near the No. 10 Fault Zone towards the north and is released by the back-thrust reverse fault near the No. 10 Fault Zone, thus forming the characteristic of mutual development.

The thrust faults of the Tazhong Uplift formed during the Middle Ordovician period and the No. 1 and No. 10 Fault Zones were finalized in the Late Ordovician, and the Central Horst Zone was active continuously for a long time prior to the sedimentation of the Triassic system (Figure 3). The No. 1 Fault is a basement-involved reverse fault, which fractures down to the basement of the Precambrian system. 


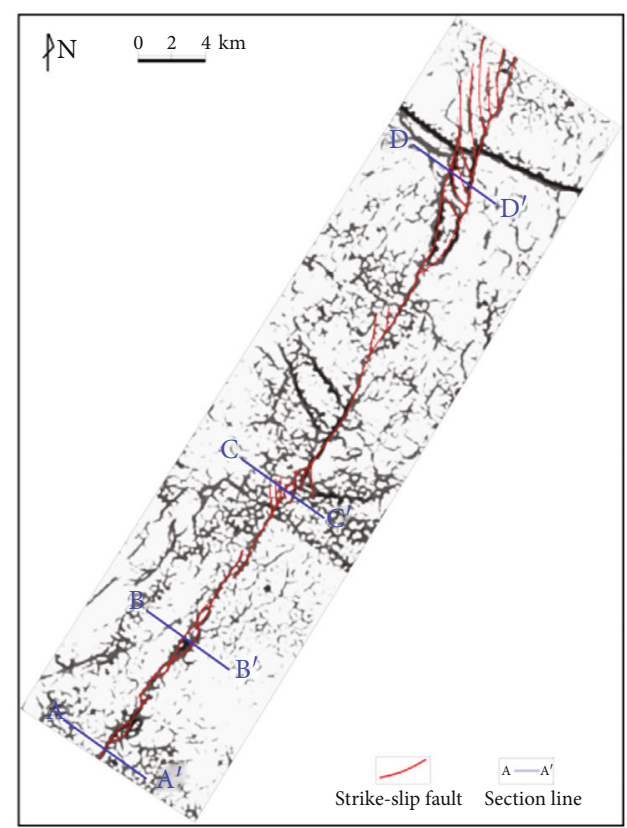

(a)

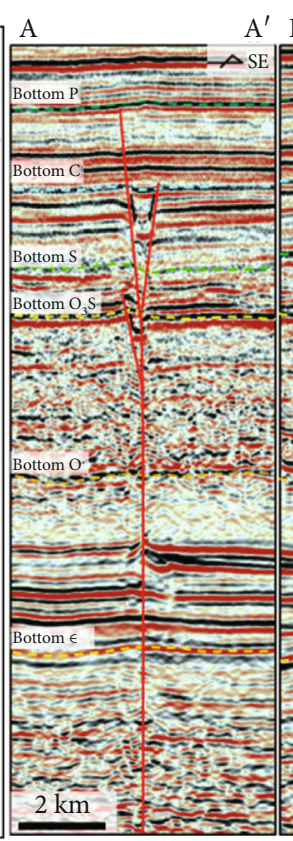

(b)
' B
$C^{\prime} \mathrm{D}$

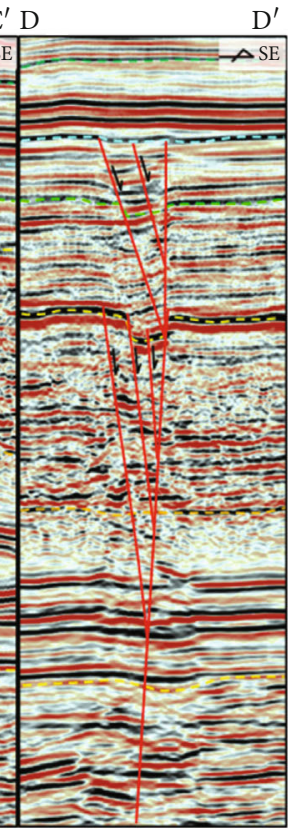

(d)

(e)

FIGURE 2: Horizontal segmentation and vertical stratification styles of the strike-slip fault zone. (a) According to the curvature attribute map of the carbonate there are linear, braided, diagonal, and ponytail segments in the fault plane. (b-e) Vertical profiles of strike-slip fault segments are as follows: (b) linear segment with an upright fault, demonstrating closed sections and small vertical fault displacement. (c) A braided segment that forms a "flower-like" bulge below the carbonate rock top and has a strongly fragmented fault zone; when further compressive or extensional faulting develops, the original fault still has capacity for hydrocarbon transport. (d) A diagonal segment which is a product of tensile and torsional stresses, with a highly fragmented fault zone and strong vertical transport capacity. (e) A horsetail segment, which is a product of tensile and torsional stress, with a high degree of fragmentation in the stress release area.

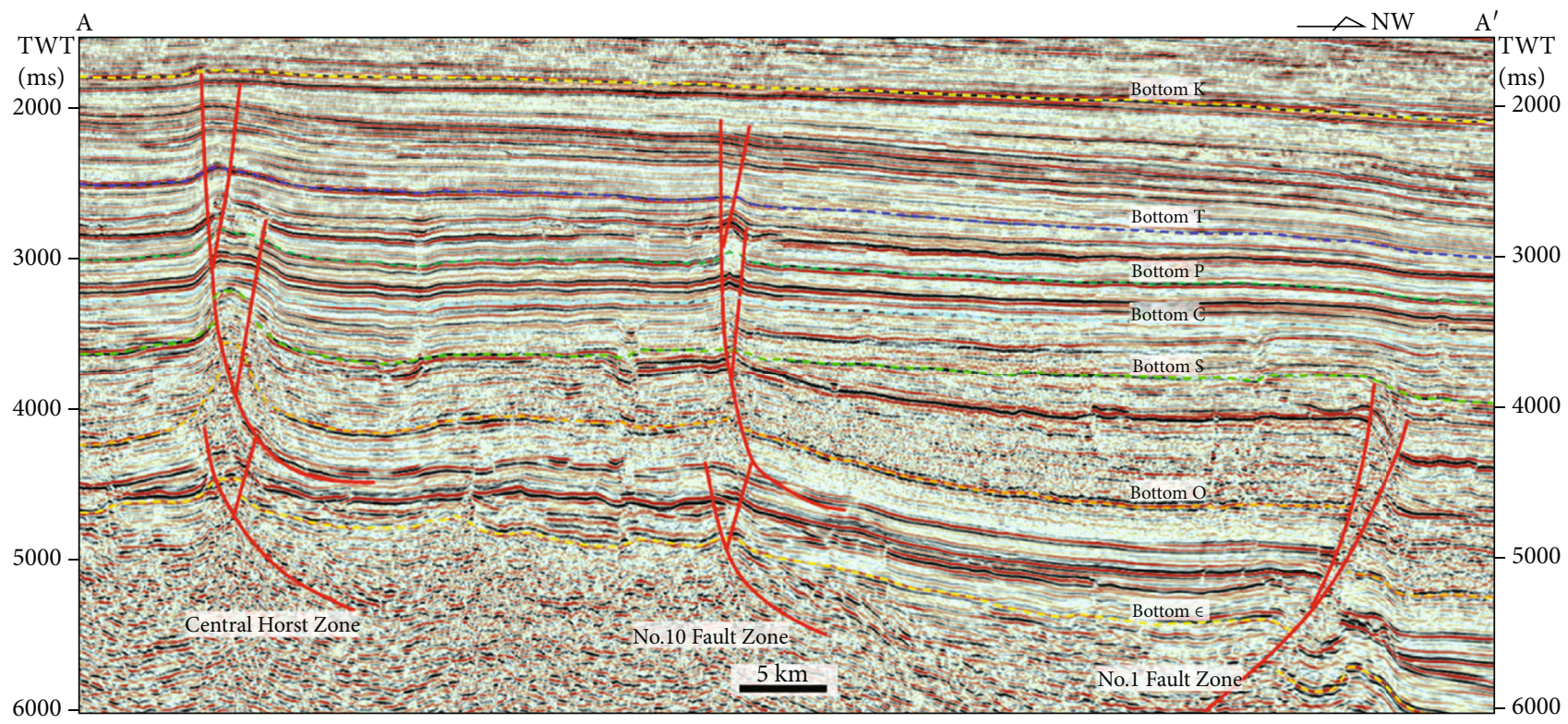

Figure 3: Seismic profile characteristics of thrust faults in the Tazhong Uplift. No. 1 Fault Zone is a basement-involved reverse fault, and No. 10 Fault Zone and the Central Horst Zone are surface detachment thrust faults which fracture down to the Middle Cambrian gypsum-salt rocks. The three thrust faults have different fault displacements, fault widths, and active periods.

Characterized by a steeply dipping upper section and shallow dipping deeper section, it spreads in the NW-SE direction, its fault width is $2-4 \mathrm{~km}$, and its fault displace- ment is up to $2000 \mathrm{~m}$. No. 10 Fault Zone and the Central Horst Zone are surface detachment thrust faults, which fracture down to the Middle Cambrian gypsum-salt rocks. 


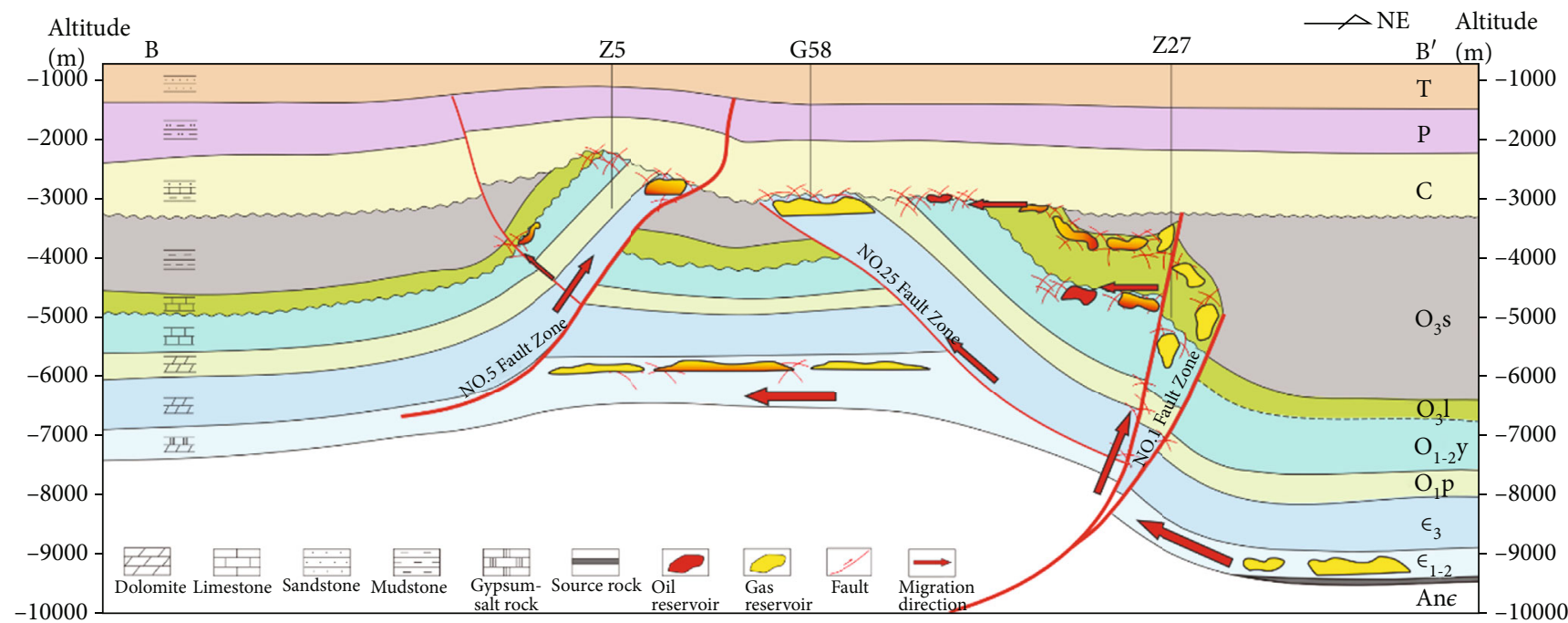

Figure 4: Profile of the carbonate rock fault unconformity pathway system of the Tazhong Uplift. Unconformities are found on the top surface of the carbonate formations and at interlayer karst fracture cavities between the formations, representing a favorable pathway system for the lateral transportation and adjustment of oil and gas.

The fault displacement and the fault width of its above salt fault are generally smaller than those of the No. 1 Fault Zone.

\subsection{Unconformity Surface and Interlayer Karst Fracture} Cavity Pathway Systems. The Yingshan Formation, together with the Lianglitage Formation, represents the largest angular unconformity surface of the carbonate rocks in the eastern and central regions of the Tazhong Uplift. The unconformity surface shows high levels of exposure, weathering, and denudation and has formed extensive weathering crust karst reservoirs. Similar to the unconformity surface, the interlayer karst fracture cavities developed on each carbonate rock bed boundary from the Upper Cambrian Series to the Ordovician system. Under the background of multistage tectonic activity, surface meteoric water or underground hydrothermal fluid infiltrated into each carbonate rock bed boundary through fractures, causing selective dissolution or metasomatism. Generally, a highly heterogeneous fracture cavity system formed within $200 \mathrm{~m}$ below the top bed boundary (Figure 4). Regardless of the unconformity surface or interlayer karst fracture cavity, at a sufficient scale and connectivity, this structure acts as a horizontal hydrocarbon migration pathway.

3.3. Dolomite Layered Pathway System. Dolomite has generally developed in the Middle-Lower Cambrian Series of the Tarim Basin, especially in the area of the Tazhong Uplift. Here, thrust faults and fractures of the Middle-Lower Cambrian Series have developed and formed dolomite reservoirs with better porosity and permeability, due to the reformation of multistage geological fluids [19]. The Middle-Lower Cambrian dolomite directly covers the source rocks of the Yurtusi Formation, and the supply of hydrocarbons is sufficient. The far-source part of the tectonic uplift area can also form "secondary hydrocarbon sources" and interacts with the reservoir above the gypsum-salt rocks via the thrust or strike-slip fault connected to it.

3.4. Distribution of Oil and Gas Reservoirs. The oil and gas reservoirs of the carbonate rock in the Tazhong Uplift are typical multistage charged complex oil and gas reservoirs. The accumulated hydrocarbons are a mix of oil charging of the Late Caledonian period, wet gas filling of the Late Hercynian period, and dry gas injecting of the Himalayan period. Featuring a complex distribution of oil, gas, and water, the reservoirs have an average depth of more than $6000 \mathrm{~m}$, and the depth difference between reservoirs in the east and west is over $2000 \mathrm{~m}$ (Figure 5) [19-22]. Four main types of oil and gas reservoirs are identified near the top of the carbonate rocks of the Middle-Upper Ordovician Series. These are the Cambrian dolomite buried hill type in the east, the Lianglitage Formation $\left(\mathrm{O}_{3} \mathrm{l}\right)$ reef-flat type of the No. 1 Fault Zone, the Yijianfang Formation interlayer karst type in the west of the Tazhong Uplift, and the weathering crust type of the top of the Yingshan Formation (widely distributed across the uplift zone). The Middle-Upper Ordovician hydrocarbon types include heavy oil, conventional oil, condensate oil, and dry gas, with a tendency from oil in the west to gas in the east. The hydrocarbons are widely distributed in the western region (for example, on the periphery of the thrust and strike-slip fault zones), and their distribution is not controlled by vertical structural positions, as highproduction wells are also distributed in relatively low-lying areas. Similar to the structural style of the Tazhong Uplift, the hydrocarbon enrichment range gradually converges from the middle to the east. In the eastern buried hill area along the No. 1 Fault Zone, the hydrocarbon enrichment range presents a linear distribution, and the proportion of unsuccessful wells in the uplift area far away from the No. 1 Fault Zone increases significantly. Carbon isotopic analysis of methane in the Upper Ordovician gas reservoirs 


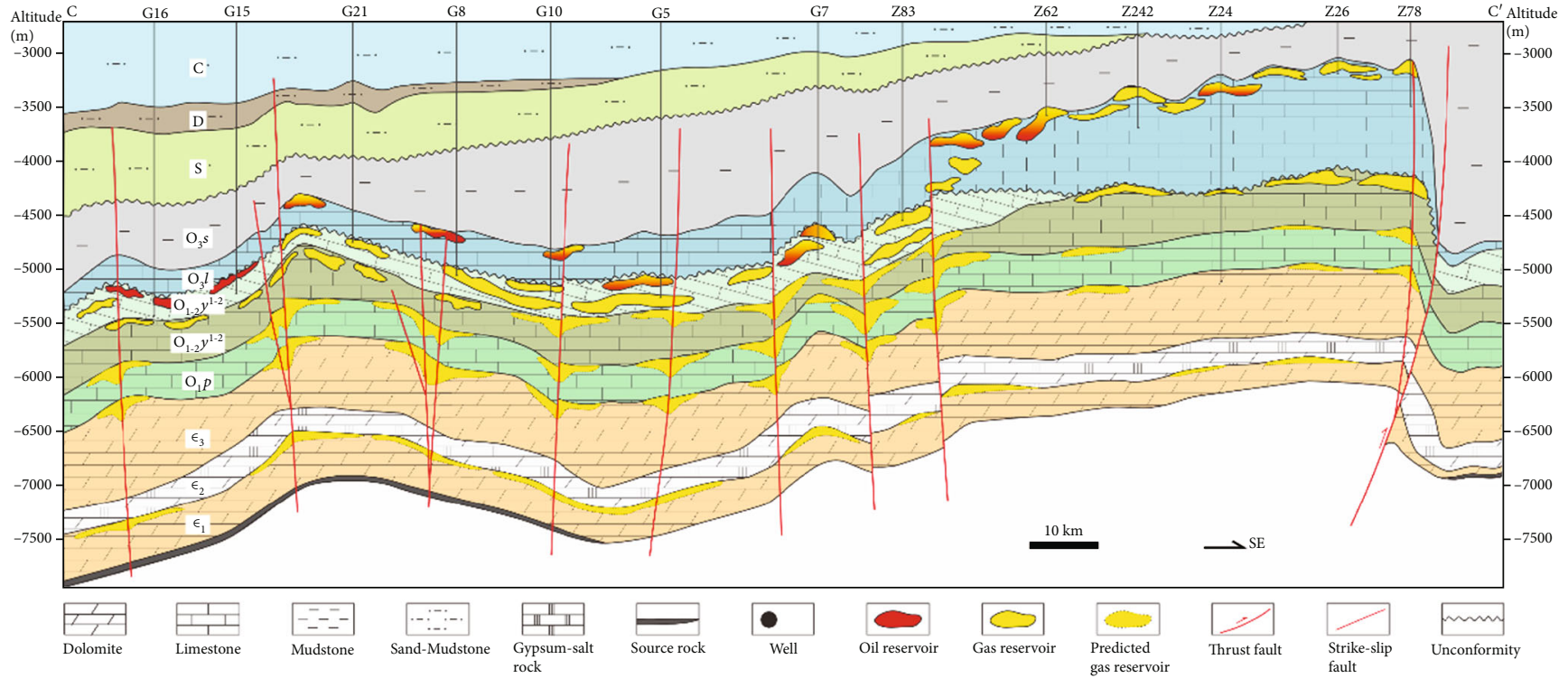

Figure 5: Section of the carbonate oil and gas reservoirs of the Tazhong Uplift. The profile of the carbonate rock, oil, and gas reservoirs of the Tazhong Uplift, showing the multilayer composite hydrocarbon accumulation characterized by oil richness in the upper assemblage and gas accumulation in the middle and lower assemblages.

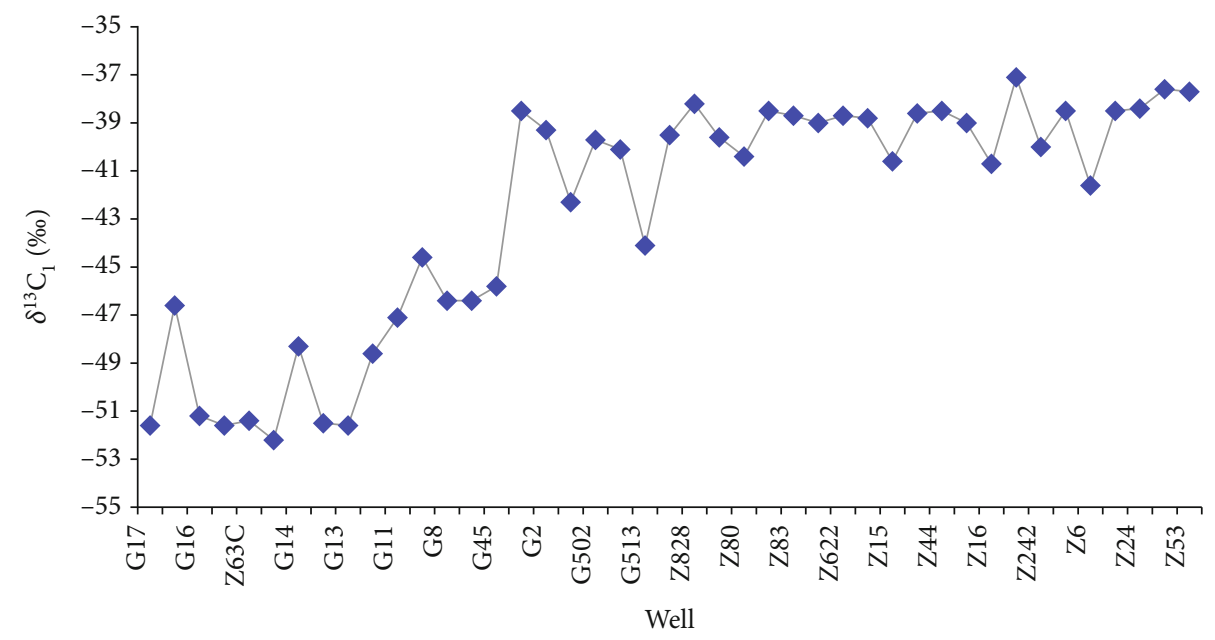

FIgURE 6: Distribution of methane carbon isotopes of the oil and gas reservoirs at the top of the carbonate rocks in the Tazhong Uplift.

(Figure 6) shows that $\mathrm{CH}_{4}{ }^{13} \delta \mathrm{C}$ ranges from -55\%o to $-50 \%$ o in the source rock area of the western region, from $-48 \%$ o to $-42 \%$ in the central region of Tazhong, and from $-42 \%$ to $-35 \%$ in the east. When combined with past studies of the types and accumulation periods of oil and gas reservoirs in Ordovician reservoirs in the Tazhong Uplift [23, 24], these data indicate that the Upper Ordovician gas in the western region of the Tazhong Uplift has the lowest maturity and earliest formation time; the Upper Ordovician gas maturity in the eastern region has the highest maturity and latest accumulation time.

The oil and gas reservoir distribution of the Tazhong Uplift varies greatly across the plane and differs significantly along the vertical direction. The middle and lower reservoir cap assemblages are dominated by gas reservoirs, while conventional oil and condensate oil occur in the upper reservoir cap. The hydrocarbon distribution is generally characterized by having oil at the top and gas at the bottom, with density increasing upwards. In Well Z162 in the central region, three reservoirs of the Lianglitage, Yingshan, and Penglaiba Formations were drilled and revealed at the same time. In these three reservoirs, three different types of hydrocarbon inclusions were discovered, with blue-white/blue/yellow-white fluorescence under ultraviolet light (UV), and the homogenization temperatures of the associated brine inclusions changed from $120^{\circ} \mathrm{C}-130^{\circ} \mathrm{C}$ to $80^{\circ} \mathrm{C}-95^{\circ} \mathrm{C}$. This indicated that hydrocarbons in the reservoirs changed from highly mature to mature with decreasing burial depth. 


\subsection{Characteristics of Main Source Rocks}

3.5.1. Determination of Main Source Rocks. The carbonate rock hydrocarbons of the platform area in the Tarim Basin come from the marine source rocks in the Manjiar-Awati Sag. However, much debate has focused on whether they come from the Middle-Lower Cambrian source rocks, the Middle-Upper Ordovician source rocks, or both of these two source rocks [25-30]. In the past 20 years, the sources of marine carbonate rock hydrocarbons in the Tarim Basin have been determined following generally well-established methods. The crude oil of the Yijianfang Formation in Well YM2 is considered representing the Middle-Upper Ordovician source rocks, and the crude oil of the Cambrian System in Well TD2 and the Silurian System in Well TZ62 is taken as the end member oil of the MiddleLower Cambrian source rocks, when studying the carbonate rock hydrocarbon sources of the Tazhong Uplift. It is believed that the hydrocarbons in this area are a mixture derived from both source rocks.

Hydrocarbons have been discovered in two adjacent formations of the Middle-Lower Cambrian Series in ZS1. According to the determination standards described above, the Middle Cambrian crude oil and Lower Cambrian natural gas of ZS1 were attributed to the Middle-Upper Ordovician and the Lower Cambrian source rock [31]. However, the Middle-Upper Ordovician Series does not have the geological conditions required for downward migration to deeper Middle-Lower Cambrian reservoirs. In addition, none of the wells of the platform area in the Tarim Basin have yielded source rocks presenting TOC $>0.5 \%$. Therefore, it is speculated that even if there were source rocks with higher TOC in the Middle-Upper Ordovician in the Manjiar Sag, they would not be sufficient to be the main source rocks in the platform area, because of their small scale. The consistency of the Ordovician crude oil biomarkers and geochemical indicators with those of the Middle-Lower Cambrian crude oil from Well ZS1 suggests that the Ordovician crude oil is mainly derived from the Cambrian source rocks. Based on the surface outcrop in the north of the Tarim Basin and the core drilling of wells LT1 and XH1, the Yurtusi Formation of the Lower Cambrian Series has the characteristics of high TOC (1\%-16\%) and stable distribution $[32,33]$. Its hydrocarbon generation potential is much higher than the current predicted geological reserves, which demonstrates the favorable geological conditions and material basis to serve as main source rocks.

3.5.2. Distribution Range of Main Source Rocks. According to the lithology logging response characteristics of the source rocks of the Yurtusi Formation encountered in Wells XH1 and LT1 [33], a logging-seismic calibration relation was established. The corresponding 3D seismic reflection characteristics represent a set of low-frequency continuous deep valley amplitude reflections with stable distribution [32]. Interpretation across the platform area, achieved by merging $2 \mathrm{D}$ and $3 \mathrm{D}$ seismic data, enabled interpretation and tracking of the source rock distribution of the Yurtusi Formation (Figure 7). This showed a close relationship with the Lower
Cambrian depositional facies investigated by previous studies [34]. During deposition of the Lower Cambrian Series, the sedimentary environment of the Tazhong Uplift changed from shallow-water shelf slope to deep-water basin towards the Manjiar Sag. The Yurtusi Formation was characterized by obvious thickening, its depocenter should be located in the north of the Manjiar Sag (in a northeast direction), and the source rocks are thicker towards the center of the basin. The source rocks of the Yurtusi Formation in the Lower Cambrian Series are distributed across the entire ManjiarAwati Sag in the north of the Tazhong Uplift but are only seen in parts of the central and western regions of the Tazhong Uplift. This is also consistent with the drilling results of Wells ZS1, ZS5, and ZH1. Source rocks failed to develop in the eastern region and Central Horst Zone of the Tazhong Uplift.

\section{Discussion}

4.1. Main Factors Controlling Accumulation. In the three reservoir cap assemblages (upper, middle, and lower) of the carbonate rocks in the Tazhong Uplift, karst fracture cavity reservoirs have generally developed; the superthick mudstone of the Sangtamu Formation, and the thick inner marl and the super-thick Middle Cambrian gypsum-salt rocks constitute the corresponding regional caprocks; and the conditions for hydrocarbon sealing and preservation are good. The hydrocarbon distribution in the abovementioned zones is subject to the source rock distribution and the source rock pathway configuration. The distribution of the source rocks determines the hydrocarbon charging pattern and the roles of various pathway systems. Therefore, this paper focuses on the pathway systems and the distribution of hydrocarbon reservoirs.

4.1.1. Pathway Systems inside and outside the Source Rocks. In the carbonate rock hydrocarbon system, pathway systems not only serve as channels for hydrocarbon migration but also a space for hydrocarbon accumulation. There are four pathway systems for carbonate rocks in the Tazhong area: faults, unconformities, interlayer karst fracture cavities, and dolomite pathway systems [7]. According to the distribution of source rocks in the Tazhong area and the close relationship between the period of tectonic activity and the time of hydrocarbon accumulation, two types of source pathway configurations (inside and outside source rocks) are identified. These were chosen to study the differences in hydrocarbon supply and transport modes.

The pathway system inside the source rocks is characterized by hydrocarbon supply from local source rocks. The reservoir is located above the source rocks. After hydrocarbons are expelled from the source rocks, they are transported vertically via a connecting fault, or horizontally via the dolomite pathway layer, or diverted to supply other connected pathway systems. The pathway system outside the source rocks is characterized by hydrocarbon supply from nonlocal source rocks. In this case, the reservoir and the source rocks are not in the same projection range. The unconformity surface and the dolomite layers are the main 


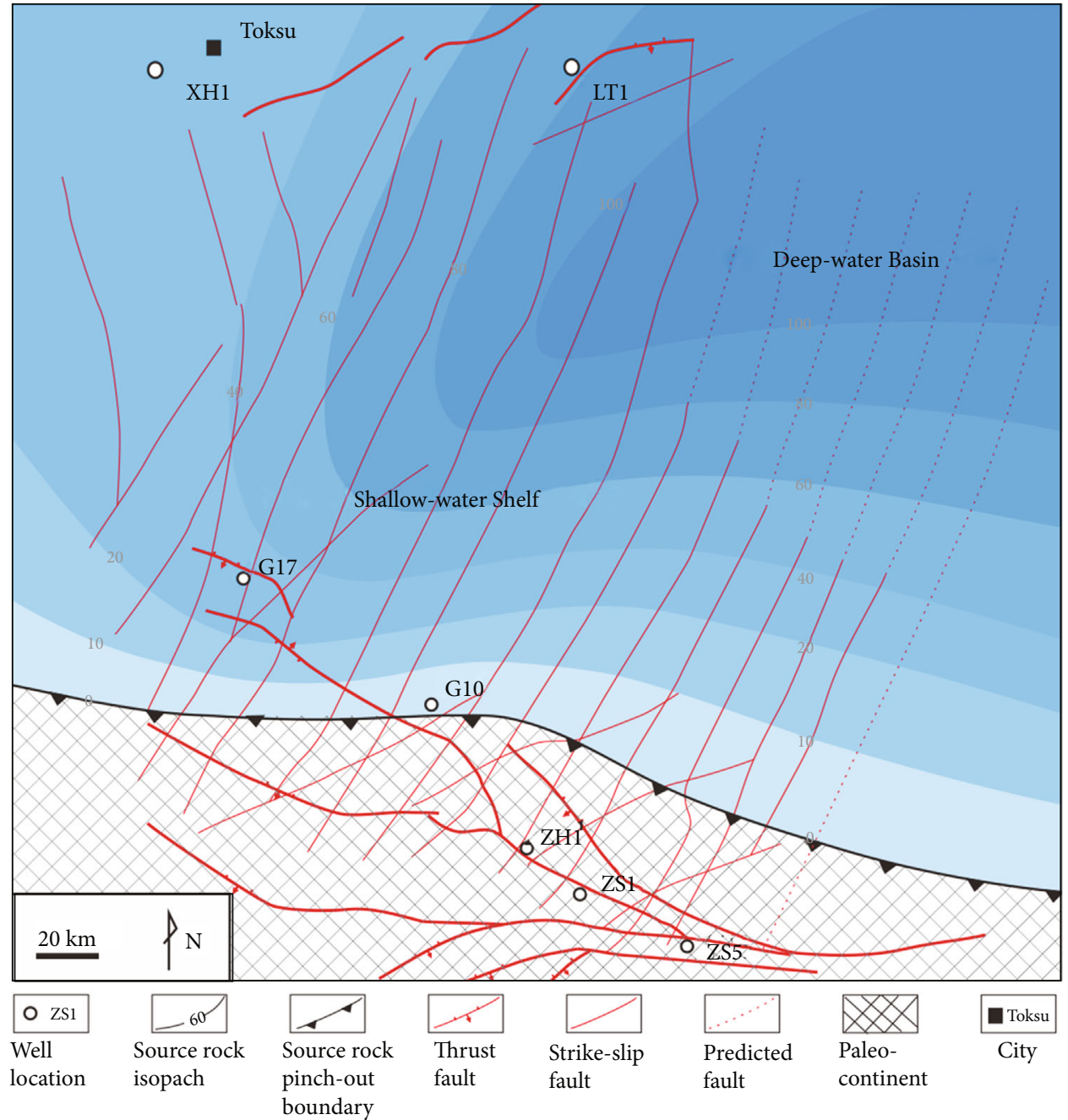

Figure 7: Yurtusi Formation of the Lower Cambrian Series and fault distribution on the periphery of the Tazhong Uplift. The depocenter of the source rocks of the Yuertusi Formation is located in the Manjiar Sag. Only the western region of the Tazhong Uplift contains source rocks, and the central and eastern regions show no source rocks. Two types of pathway systems (inside and outside the source rock) are identified.

pathways connecting source-distal hydrocarbons, and the hydrocarbon transport characteristics are thus strongly influenced by paleogeomorphology and paleostructural ridges. After the hydrocarbons are discharged from the source rock, two or more migration stages are required for hydrocarbon accumulation and reservoir formation. In the faulted area, hydrocarbons that are laterally transported will change their flow direction by the fault, eventually accumulating at the top of the reservoir.

4.1.2. The Role of Strike-Slip Faults in Oil and Gas Transport. Previous studies of the faults of the Tazhong Uplift have usually analyzed the multistage superposed products as a whole $[10,15]$. However, the superposition of structural styles and the properties of multistage strike-slip faults differ from those of single-stage faults. The differences in their tectonic styles are superposed on the profile of the Tazhong Uplift, leading to vertical stratification (Figure 2) and to different hydrocarbon transport capacities above and below the stress transition surfaces of different stages of strike-slip faults (Figure 8). Early faults present as linear compression segments-regardless of whether they are compressed or extended after superposition-and show an unchanged degree of fragmentation and poor hydrocarbon migration conditions; in contrast, if the early faults develop a flowerlike structure under compression or extension, then the fragmentation of the fault zone is conducive to vertical hydrocarbon migration. When the superimposed fault is a linear compression segment, hydrocarbons are preserved under the transition surface. When the superimposed fault has a flower-like structure, the fault zone is connected both upwards and downwards, and hydrocarbons will continue to move upward, charging favorable reservoirs along the way, and relatively enriching rocks lying under the top fault sealing surface (Figure 8 ). Statistics on the production capacity of hydrocarbon wells and their distance from the core of the fault zone show that the hydrocarbons are mainly enriched within a zone extending $1000 \mathrm{~m}$ from the strike- 

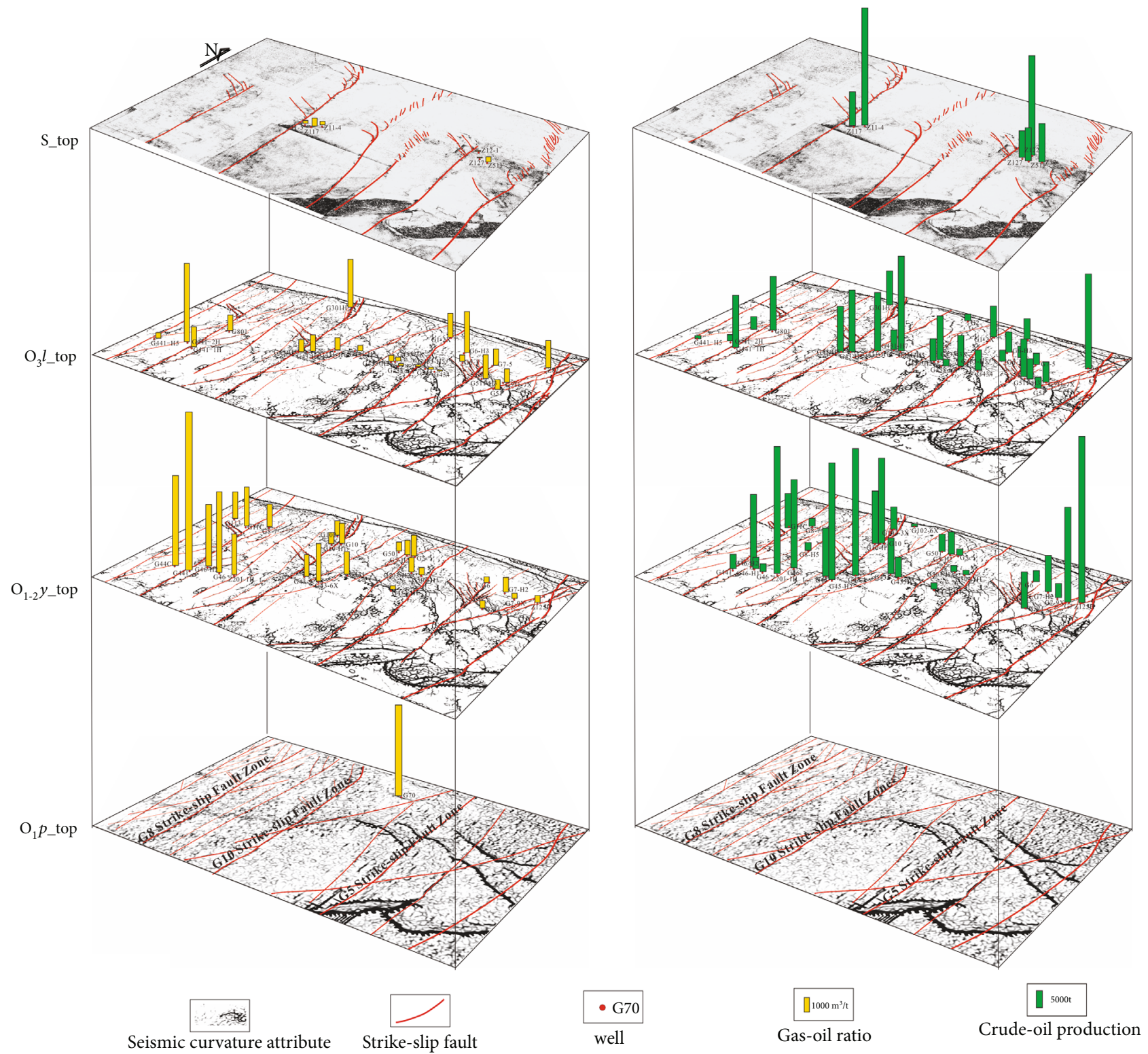

Figure 8: Distribution of the gas-oil ratio and crude oil production of carbonate reservoirs in the central Tazhong Uplift. In the same strike slip fault zone, the gas-oil ratio and crude oil production tend to decrease upwards in the southern compression section, while in the northern extension section, the opposite trend is observed.

slip fault zone. At greater distances, the hydrocarbon charging intensity will decrease (Figure 9).

The above interpretation of how multistage superposed strike-slip faults influence hydrocarbon transport is based on the premise that hydrocarbons come from underlying hydrocarbon sources. Under the condition of hydrocarbons coming migrating laterally, then instead the horizontal transport of the strike-slip fault is dominant. The strikeslip fault zone enables hydrocarbon redistribution via short-distance horizontal transport, similar to the horizontal hydrocarbon transport associated with tectonic ridges.

4.1.3. The Role of Thrust Faults in Oil and Gas Transport. Statistics show that the success rate of oil and gas wells in the area with obvious vertical fault displacement in the No.
1 Fault Zone is $85 \%$, while the proportion of stripper wells and failed wells in the area with ambiguous fault displacement can reach up to $77.8 \%$. That is, the thrust fault activity is positively correlated with the level of hydrocarbon enrichment in the fault zones, as demonstrated by the formation of major fields in the upper reservoir cap assemblage of the Ordovician system in the exploration areas of both the No. 1 and No. 10 Fault Zones. Although the activity time of the three groups of thrust faults does not match with the time of hydrocarbon charging (especially during the Late Hercynian period and the Himalayan period), these faults are still important pathways for multistage hydrocarbon charging, perhaps due to the large vertical fault displacement and wide fault fragmentation zone formed by the thrust faults. Under the paleouplift background, source-distal 


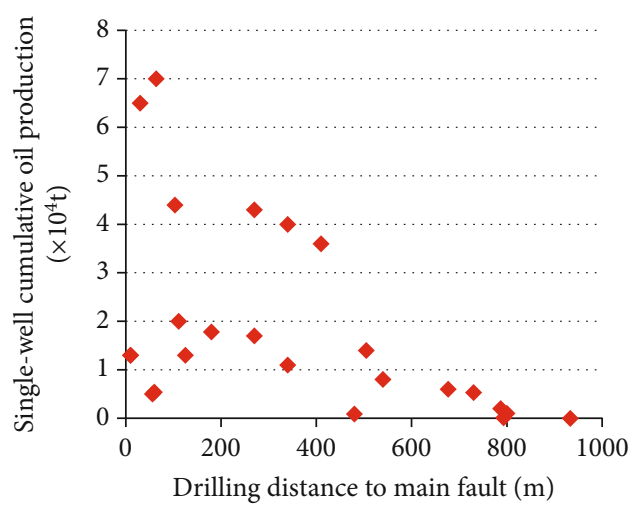

(a)

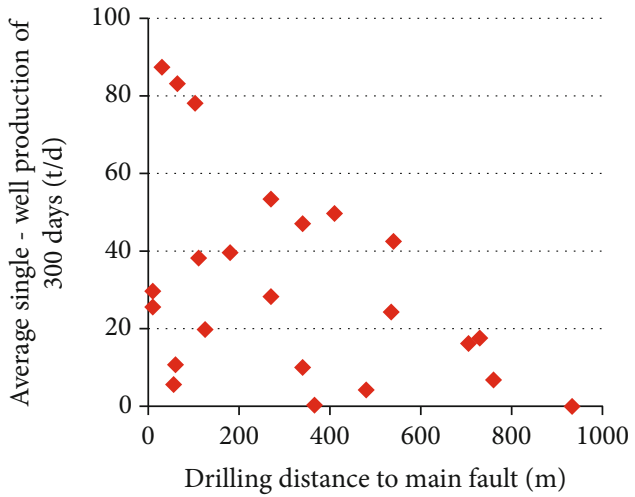

(b)

FIGURE 9: Cross-plots of single-well cumulative oil production and average single-well production against distance from the main fault in the western region of the Tazhong Uplift. (a) Cross-plot for single-well cumulative oil production against distance from the main fault. (b) Cross-plot for 300-day average single-well production against distance to the main fault. Closer to the main fault, the overall hydrocarbon production is higher. Some oil and gas reservoirs that are too close to the strike-slip fault zone are not as rich as those at a distance of 200-500 m, which might be related to the upward hydrocarbon readjustment and remigration when close to the strike-slip fault zone.

hydrocarbons tend to migrate from depressions to high points. No. 1 Fault Zone represents the northern boundary of the Tazhong Uplift, and with its large fault displacement and fault width, it effectively intercepts the hydrocarbons charged from the northern depression to the southern uplift. The hydrocarbons accumulated around the three reservoir cap assemblages (upper, middle, and lower) on the periphery of the No. 1 Fault Zone.

\subsubsection{The Role of Layered Pathway in Oil and Gas Transport.} Previous studies have shown that the unconformity surface of clastic rocks features high porosity and permeability and could be used as an effective pathway for long-distance hydrocarbon transport [35]. Nevertheless, limited by the high heterogeneity of carbonate rocks, the unconformity surface, and the interlayer karst fracture cavity aggregate are indeed inferior to those of clastic rocks in terms of their horizontal extent and continuity. The unconformity surface and the interlayer karst fracture cavities in the study area are not in contact with the source rocks, and the hydrocarbon supply capacity is limited. Therefore, they mainly act as pathways for local hydrocarbon adjustment.

In the source rock area, when hydrocarbons migrate from thrust faults or strike-slip faults to the karst fracture cavity area, and if the middle and upper reservoir cap assemblages present a sudden variation of rock porosity and permeability on both sides of the faults, then hydrocarbons migrate laterally into the reservoir and accumulate at the top of the envelope plane. When this karst fracture cavity system is relatively independent, hydrocarbons can become enriched and will accumulate; when the connectivity is good, hydrocarbons can migrate further, reaching higher storage spaces, to forming a pathway for hydrocarbon adjustment in the reservoir. In the area outside the source rocks, the hydrocarbons from the northern Manjiar Sag first enter No. 1 Fault Zone, becoming enriched and accumulating within 1.5 to $4.5 \mathrm{~km}$ from the No. 1 Fault Zone. The Upper
Cambrian-Upper Ordovician unconformity surface or interlayer karst fracture cavity connected to the No. 1 Fault Zone enables lateral hydrocarbon migration and adjustment of the hydrocarbons vertically transported from the thrust faults. The hydrocarbon enrichment on the top of the carbonate rocks is then likely controlled by the paleostructure and paleogeomorphology. Hydrocarbons accumulate in tectonic high points, like ridges and peak clusters, while low positions of the paleogeomorphology represent aquifers or gas reservoirs with high water saturation.

As a layered pathway system, the Lower-Middle Cambrian dolomite's transport capacity depends strongly on the potential difference caused by the paleotectonic background. Tectonic ridges and low uplift both present favorable hydrocarbon migration pathways and accumulation areas. In the source rock areas in the west of the Tazhong Uplift, a large range of paleotectonic uplifts were maintained and/or inherited during the main tectonic activity periods, such as the Middle Caledonian, the Early Hercynian, the Late Hercynian, and the Himalayan, thus providing good conditions for hydrocarbon accumulation in the dolomite reservoirs under gypsum-salt rocks. At the same time, the faults of the superthick gypsum-salt rocks became pathways for upward adjustment of some of the hydrocarbons, leading to hydrocarbon enrichment and accumulation near the fault zone in the fracture cavity system of the Upper Cambrian-Ordovician series.

Taking wells ZS1 and ZS5 in the eastern region of the Tazhong Uplift as examples, there are no source rocks in the surrounding area, while industrial hydrocarbon reservoirs from the Lower Cambrian source rocks have been found in the Middle-Lower Cambrian. The Lower-Middle Cambrian dolomite is identified as the layered hydrocarbon pathway system. The Lower Cambrian hydrocarbons in the northern Manjiar Sag migrated to the buried hill area in the east of the Tazhong Uplift. In this way, hydrocarbons accumulate and become enriched in high paleotectonic positions or in dominant migration pathways. 
4.2. Hydrocarbon Migration and Accumulation. In the source rock area of the Tazhong Uplift, hydrocarbons are derived from the underlying source rocks. The superthick Middle Cambrian gypsum salt rocks are partitioned into two reservoir-forming assemblages (upper and lower): the Middle-Lower Cambrian dolomite reservoir is in direct contact with the Lower Cambrian source rocks under the gypsum salt rocks, and the hydrocarbon migration and enrichment are controlled by multistage tectonic evolution and changes in reservoir properties. The Upper CambrianUpper Ordovician hydrocarbon accumulation is closely related to the distribution of faults (Figure 10(a)). The thrust and strike-slip faults directly connecting to the Lower Cambrian hydrocarbon sources act as efficient vertical pathways to transport hydrocarbons to the overlying fracture cavity reservoirs. With a fault displacement greater than the thickness of the gypsum-salt rocks of the No. 1 Fault Zone, the basement-involved thrust fault directly connects to the oil source and is a favorable pathway for the threestage hydrocarbon charging. Most of the prolific hydrocarbon wells are distributed within $5000 \mathrm{~m}$ of the No. 1 Fault Zone, with dryness coefficients (0.91-0.94) that are significantly higher than the average for the western region (0.66-0.90). No. 10 Fault Zone is a surface detachment thrust fault. Its fault displacement is less than the thickness of the gypsum-salt rocks, which is not conducive to vertical hydrocarbon migration. Possibly affected by further enhancement of the seal integrity of the late gypsum-salt caprock, poor reservoirs formed near the No. 10 Fault Zone, without late natural gas charging.

The hydrocarbon charging and distribution of carbonate rocks above the Middle Cambrian gypsum salt rocks are also controlled by the strike-slip fault zone and its related multistage activity. In the northern region, the strike-slip faults are mostly manifested as the superposition of extensional or compressive bending belts in the middle and upper reservoir cap assemblages. The crude oil of the Late Caledonian period or the Late Hercynian period migrated vertically to the reservoirs on both sides of the fault zone through the strike-slip faults. Sealed by the superthick mudstone of the Sangtamu Formation, the crude oil is most strongly enriched on the top of the limestone. Although the strike-slip faults maintained the hydrocarbon transport capacity during the late stage, this may have been limited by the sealing of the gypsum salt rocks, and insufficient natural gas to migrate through the gypsum salt rocks. Consequently, there are generally oil reservoirs on both sides of the strike-slip fault zone, the gas-oil ratio is low $\left(65-1824 \mathrm{~m}^{3} / \mathrm{m}^{3}\right)$, the dryness coefficient of natural gas is $0.66-0.94$, and the natural gas is characterized by the associated gas in the oil reservoir.

If there is a suitable reservoir cap assemblage on the periphery of the fault zone, then a multilayer superimposed compound oil and gas reservoir will probably form. In the southern region, the vertical fault displacement and strikeslip fault displacement of the strike-slip faults with linear compression formed during the Middle Ordovician period are small, and the level of fragmentation of these faults is low. Poor reservoirs generally formed near the fault zones, indicating that the strike-slip faults have weak hydrocarbon transport capacity in deep layers, and little crude oil can migrate upwards in the early stage. As the Late-middle Cambrian caprock became more strongly sealed, the late natural gas rarely charged into the Upper Cambrian-Upper Ordovician Series and remained preserved under the Middle Cambrian gypsum salt rocks.

The Cambrian source rocks in the Manjiar Sag, in the north of the Tazhong Uplift, are the main hydrocarbon sources in the current accumulation area. The hydrocarbons of the Manjiar Sag can accumulate in the remote uplift area only by lateral transport (Figure 10(b)). Except for the vertical hydrocarbon transport by the No. 1 and No. 10 thrust faults of the Tazhong Uplift, the strike-slip faults mainly provide lateral hydrocarbon transport. The No. 1 Fault Zone is closest to the hydrocarbon source and crosses the MiddleLower Cambrian layered pathway system. The hydrocarbons migrating from north to south encounter No. 1 Fault Zone on the northern boundary of the uplift, undergoing an important change in flow direction. Migrating upward through No. 1 Fault Zone, part of the hydrocarbons form a compound oil and gas reservoir after encountering a favorable reservoir cap assemblage in the Cambrian-Ordovician system on the periphery of the fault zone. Since the No. 1 Fault Zone is vertically fragmented only to the mudstone of the Sangtamu Formation, its terminal oil and gas reservoir is the reef shoal storage space of the Lianglitage Formation. After the top hydrocarbons reach the trap's spill point, they horizontally adjust and migrate into the platform of the reservoir along the fracture cavity on the top of the carbonate rocks or the northeast strike-slip fault zone. The remaining hydrocarbons that do not change their flow direction along the No. 1 Fault Zone continue to migrate to the uplift area along the Middle-Lower Cambrian layered pathway system, becoming enriched at high tectonic positions of the MiddleLower Cambrian Series or within the lithologic traps. In the control area of the pathway system outside the source rocks, hydrocarbon migration and enrichment under the gypsumsalt rock is restricted by the layered pathway system. The height of the paleostructure and paleogeomorphology is the key factor controlling hydrocarbon enrichment.

In addition to the leading role of source rocks and pathway systems during carbonate hydrocarbon accumulation in the Tazhong Uplift, the influence of the Middle Cambrian gypsum salt caprock cannot be ignored. In the western region of the Tazhong Uplift, as the burial depth increases, the fluid plasticity of the gypsum-salt rock becomes more prominent [36], and its ability to seal hydrocarbons is also greatly enhanced. The superthick gypsum salt caprock seals late-stage natural gas under the gypsum-salt rock. The Lower Cambrian dolomite reservoir is rich in natural gas, while the upper and middle reservoir caps above the gypsum salt rock are rarely charged with natural gas from underlying source rocks; these upper or middle reservoir caps are characterized by heavy methane carbon isotopes and rich oil. Although there is no source rock in the eastern region of the Tazhong Uplift, the high tectonic positions of the uplift tend to be the targets of lateral hydrocarbon migration. The late-stage dry natural gases from the northern Manjiar Sag migrate through the dolomite layers or migrate towards 


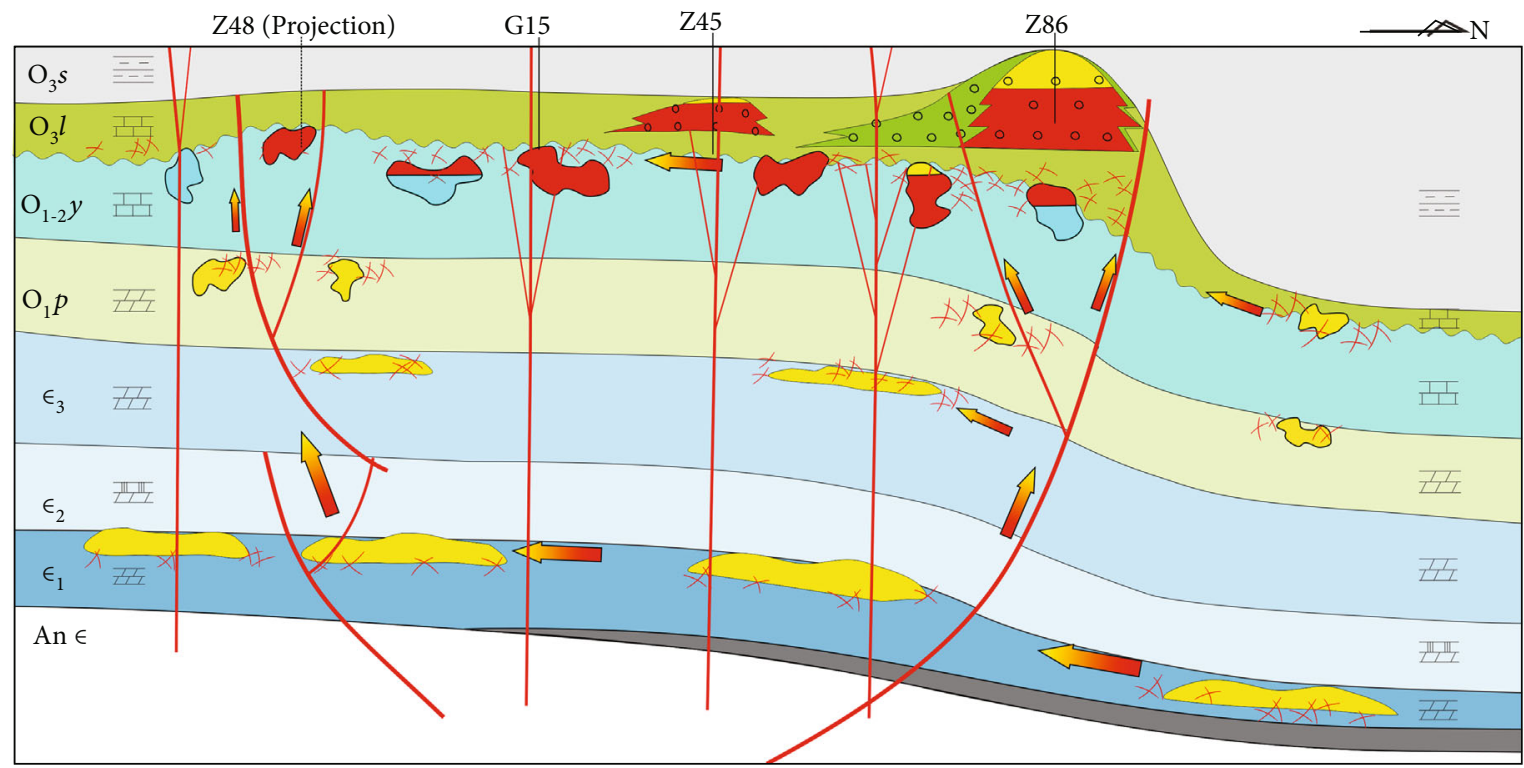

(a)

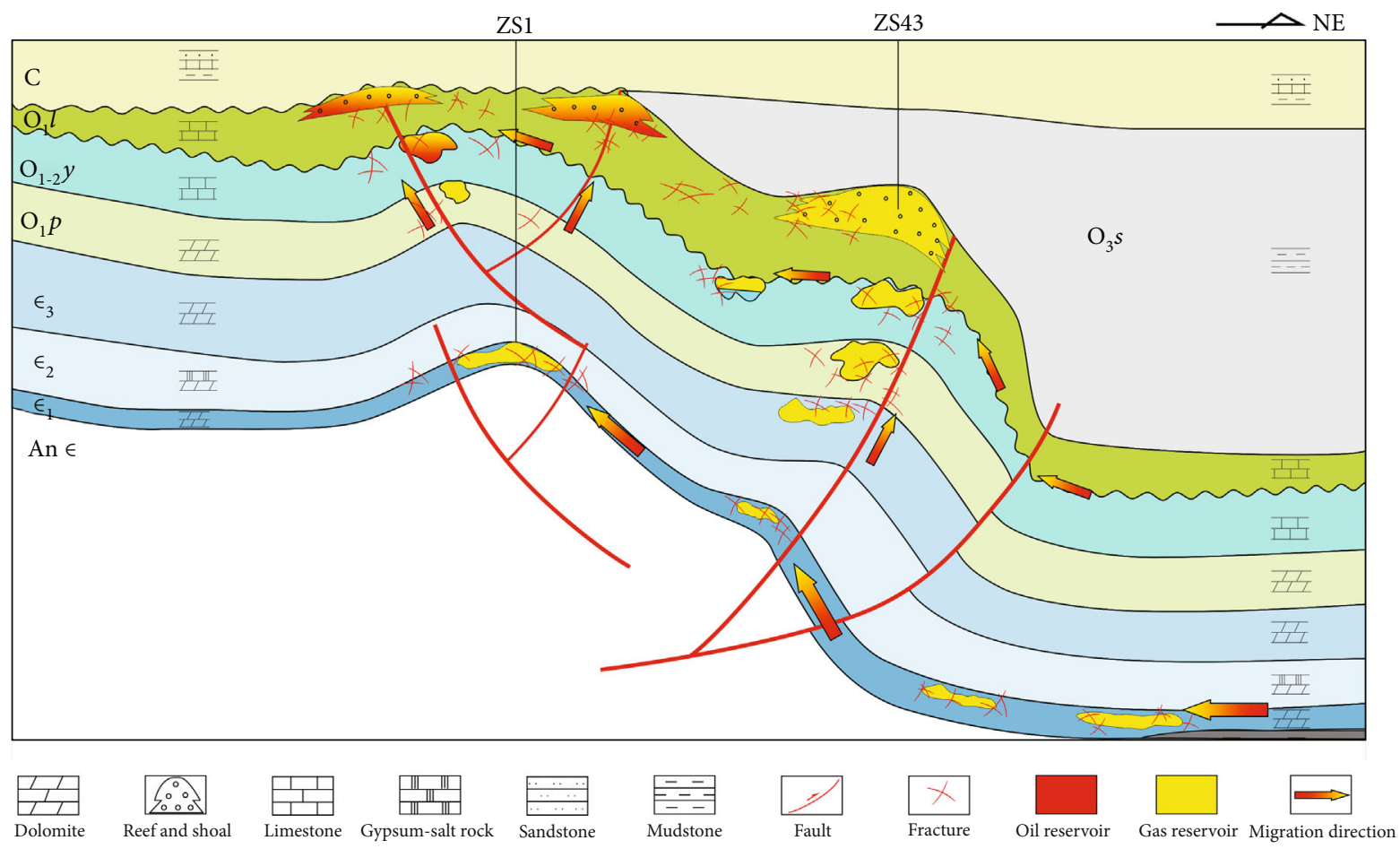

(b)

FIGURE 10: Hydrocarbon transport modes inside and outside the carbonate source rocks in the Tazhong Uplift. (a) Modes of hydrocarbon transport inside the source rock. The source rocks of the Yurtusi Formation in the Lower Cambrian Series supply the hydrocarbons. The hydrocarbon accumulations of the lower assemblage are controlled by tectonic lithologic traps, and those of the middle and upper assemblages migrate vertically via the No. 1 Fault Zone and strike-slip faults. The hydrocarbon transport capacity of the No. 1 Fault Zone is related to the fault displacement and that of strike-slip faults is related to the multistage fault superposition pattern. The overall hydrocarbon enrichment in the northern area is higher than that in the southern area. (b) Mode of hydrocarbon transport outside the source rock. The hydrocarbons come from the northern Manjiar Sag. The hydrocarbon accumulation of the lower assemblage is controlled by tectonic lithologic traps. Affected by the No. 1 Fault Zone, the hydrocarbons of the middle and upper assemblages change their flow direction to migrate vertically and accumulate along the No. 1 Fault Zone; they then accumulate in the karst fracture cavity development area of the middle and upper assemblages. 
the Tazhong Uplift via tectonic ridges, thus charging the middle and upper reservoir cap assemblages through the No. 1 Fault Zone and forming reservoirs in the platform margin belt. The surplus natural gas laterally adjusts via the unconformity surface. Therefore, the eastern region is characterized by its light carbon isotopes in methane and high density $\left(0.83 \mathrm{~g} / \mathrm{cm}^{3}\right)$ of condensate oil.

\section{Conclusions}

Based on our evaluation of the temporal-spatial coupling between different pathway systems and the main hydrocarbon source rocks in the Tazhong Uplift, this paper discusses the hydrocarbon migration and accumulation characteristics of carbonate rocks under the control of various pathway systems. The following conclusions are drawn:

(1) Our proposed source pathway transport characteristics of the carbonate rocks in the Tazhong Uplift provide a new basis for detailed investigation of hydrocarbon migration in carbonate rocks. After determining the sources of marine carbonate rock hydrocarbons in the Tazhong Uplift, this paper studied the distribution, activity, and classification of various pathway systems (namely, those inside and outside the source rocks). This was achieved through detailed analysis of the source rocks of the Yurtusi Formation in the Lower Cambrian Series in combination with well logging and seismic facies

(2) For the hydrocarbon accumulation system within source rocks, hydrocarbon migration and enrichment are vertically differentiated. The Middle Cambrian gypsum salt rocks serve as the boundary, above which hydrocarbons are transported vertically by thrust and strike-slip faults, becoming enriched in multiple layers on the periphery of the thrust and strike-slip fault zones. In addition, the multistage superposition pattern of strike-slip faults controls the differences in hydrocarbon enrichment of the fault zones. Below the gypsum-salt rocks, the layer pathway system controls the hydrocarbon migration, while the topography of the paleostructure and paleogeomorphology controls the hydrocarbon accumulation

(3) For the hydrocarbon accumulation system outside of the source rock, hydrocarbon migration and enrichment are restricted by the layer pathway system, and the height of the paleostructure and paleogeomorphology is the key factor controlling hydrocarbon enrichment. The Tazhong No. 1 Fault is the main vertical pathway system in the area underlain by no source rocks, and hydrocarbons have become enriched at the periphery of the Middle-Lower Cambrian and No. 1 Fault Zone

\section{Data Availability}

The data used to support the findings of this study are available from the corresponding author upon request.

\section{Conflicts of Interest}

The authors declare that they have no conflicts of interest.

\section{Acknowledgments}

This work was funded by the National Science and Technology Major Project (No. 2016ZX05004-003). We appreciate the Research Institute of Petroleum Exploration and Development of PetroChina Tarim Oilfield Company for providing part of the research data. We are particularly grateful to Dr. Yongquan Chen, Senior Engineer Zhenghong Zhang, and Senior Engineer Dong Sun for their help and constructive comments during our preparation process of the manuscript.

\section{References}

[1] C. Jia and G. Wei, "Structural characteristics and petroliferous features of Tarim Basin," Chinese Science Bulletin, vol. 47, no. S1, pp. 1-11, 2002.

[2] J. Du, X. Zhou, Q. Li, G. Wu, W. Pan, and T. Yang, "Characteristics and controlling factors of the large carbonate petroleum province in the Tarim Basin, NW China," Petroleum Exploration and Development, vol. 38, no. 6, pp. 652-661, 2011.

[3] Z. Wang, K. Zhao, G. Wu et al., "Characteristics and main controlling factors of the upper ordovician reef-bank reservoir development in the Tazhong 1 slope-break zone," Oil \& Gas Geology, vol. 28, no. 6, pp. 797-801, 2007.

[4] L. Jiang, W. Pan, C. Cai et al., "Fluid mixing induced by hydrothermal activity in the ordovician carbonates in Tarim Basin, China," Geofluids, vol. 15, no. 3, 498 pages, 2015.

[5] A. Aydin, "Fractures, faults, and hydrocarbon entrapment, migration and flow," Marine and Petroleum Geology, vol. 17, no. 7, pp. 797-814, 2000.

[6] C. D. P. Giwelli, L. Esteban, M. B. Clennell et al., "Laboratory observations of fault transmissibility alteration in carbonate rock during direct shearing," Geofluids, vol. 16, no. 4, 672 pages, 2016.

[7] D. Zhang, Y. Wang, Z. Xiao, M. Wu, M. Zheng, and W. Zhang, "Paleozoic carrier system in platform-basin transitional area of Tarim basin and future exploration," Oil \& Gas Geology, vol. 27, no. 5, pp. 604-613, 2006.

[8] G. Wu, H. Yang, T. Qu, H. Li, C. Luo, and B. Li, "The fault system characteristics and its controlling roles on marine carbonate hydrocarbon in the central uplift, Tarim basin," Acta Petrologica Sinica, vol. 28, no. 3, pp. 793-805, 2012.

[9] X. Wang, X. Lv, G. Liu, Y. Zhang, W. Jiao, and X. Hua, "Hydrocarbon carrier system of carbonate rock and exploration direction in Tahe Oilfield, Tarim Basin," Petroleum Geology \& Experiment, vol. 1, pp. 14-18, 2012.

[10] Y. Neng, H. Yang, and X. Deng, "Structural patterns of fault broken zones in carbonate rocks and their influences on petroleum accumulation in Tazhong Paleo-uplift, Tarim Basin, NW China," Petroleum Exploration and Development, vol. 45, no. 1, pp. 40-50, 2017.

[11] T. MANZOCCHI, C. CHILDS, and J. J. WALSH, "Faults and fault properties in hydrocarbon flow models," Geofluids, vol. 10, 113 pages, 2010.

[12] S. Zhang, B. Zhang, B. Li, G. Zhu, J. Su, and X. Wang, "History of hydrocarbon accumulations spanning important tectonic 
phases in marine sedimentary basins of China: taking the Tarim Basin as an example," Petroleum Exploration and Development, vol. 38, no. 1, pp. 1-15, 2011.

[13] W. Zhao, G. Zhu, J. Su, J. Hai, and Y. Zhu, "Study on the multistage charging and accumulation model of Chinese marine petroleum: example from eastern Lungu area in the Tarim Basin," Acta Petrologica Sinica, vol. 28, no. 3, pp. 709-721, 2012.

[14] W. Zhao, S. Hu, W. Liu, T. Wang, and H. Jiang, "The multistaged "golden zones" of hydrocarbon exploration in superimposed petroliferous basins of onshore China and its significance," Petroleum Exploration and Development, vol. 42, no. 1, pp. 1-13, 2015.

[15] T. Jiang, J. Han, G. Wu et al., "Differences and controlling factors of composite hydrocarbon accumulations in the Tazhong uplift, Tarim Basin, NW China," Petroleum Exploration and Development, vol. 47, no. 2, pp. 213-224, 2020.

[16] U. S. Allan, "Model for hydrocarbon migration and entrapment within faulted structures," American Association of Petroleum Geologists Bulletin, vol. 73, pp. 803-811, 1989.

[17] Y. Xiao, G. Wu, Y. Lei, and T. Chen, “Analogue modeling of through-going process and development pattern of strike-slip fault zone," Petroleum Exploration and Development, vol. 44, no. 3, pp. 340-348, 2017.

[18] G. Zhu, S. Zhang, H. Wang et al., "The formation and distribution of deep weathering crust in North Tarim basin," Acta Petrologica Sinica, vol. 25, no. 10, pp. 2384-2398, 2009.

[19] Z. Wang, H. Xie, Y. Chen, Y. Qi, and K. Zhang, "Discovery and exploration of Cambrian subsalt dolomite original hydrocarbon reservoir at Zhongshen-1 well in Tarim Basin," China Petroleum Exploration, vol. 19, no. 2, pp. 1-13, 2014.

[20] J. Han, H. Zhang, H. Yu et al., "Hydrocarbon accumulation characteristic and exploration on large marine carbonate condensate field in Tazhong Uplift," Acta Petrologica Sinica, vol. 28, no. 3, pp. 769-782, 2012.

[21] H. Pang, J. Chen, X. Pang, L. Liu, K. Liu, and C. Xiang, "Key factors controlling hydrocarbon accumulations in Ordovician carbonate reservoirs in the Tazhong area, Tarim basin, western China," Marine and Petroleum Geology, vol. 43, pp. 88-101, 2013.

[22] G. Zhu, B. Zhang, H. Yang, J. Su, and J. Han, "Origin of deep strata gas of Tazhong in Tarim Basin, China," Organic Geochemistry, vol. 74, pp. 85-97, 2014.

[23] K. LIU, J. Bourdet, B. Zhang, N. Zhang, X. Lu, and S. Liu, "Hydrocarbon charge history of the Tazhong Ordovician reservoirs, Tarim Basin as revealed from an integrated fluid inclusion study," Petroleum Exploration and Development, vol. 2, pp. 171-180, 2013.

[24] N. Zhang, L. Tian, Y. Xing, and X. Lu, "Characteristic of hydrocarbon fluid inclusions and analysis of reservoir formation in Ordovician reservoir of Tazhong area, Tarim basin," Acta Petrologica Sinica, vol. 27, no. 5, pp. 1548-1556, 2011.

[25] X. Pang, Q. Yu, X. Guan, S. Li, and F. Jiang, "Evolution and movement of source kitchens and their control of oil and gas in the Tarim Cratonic Basin, China," Energy Exploration \& Exploitation, vol. 30, no. 2, pp. 239-272, 2012.

[26] D. Song, T. Wang, and M. Li, "Geochemistry and possible origin of the hydrocarbons from wells Zhongshen1 and Zhongshen1C, Tazhong Uplift," Science China Earth Sciences, vol. 59, no. 4, pp. 840-850, 2016.
[27] Y. Pan, B. Yu, B. Zhang, and G. Zhu, "Origins and differences in condensate gas reservoirs between east and west of Tazhong uplift in the Ordovician Tarim Basin, NW China," Journal of Earth Science, vol. 28, no. 2, pp. 367-380, 2017.

[28] J. Su, Y. Wang, X.-M. Wang et al., "Impact of formation water on the generation of $\mathrm{H} 2 \mathrm{~S}$ in condensate reservoirs: a case study from the deep Ordovician in the Tazhong Uplift of the Tarim Basin, NW China," Petroleum Science, vol. 14, no. 3, pp. 507519, 2017.

[29] Y. Li, Y. Xiong, Q. Liang et al., "The application of diamondoid indices in the Tarim oils," AAPG Bulletin, vol. 102, no. 2, pp. 267-291, 2018.

[30] H. Zhang, Z. Cai, F. Hao, L. Qi, L. Yun, and L. Jiang, "Hydrogeomorphologic architecture of epikarst reservoirs in the Middle-Lower Ordovician, Tazhong Uplift, Tarim Basin, China," Marine and Petroleum Geology, vol. 98, pp. 146-161, 2018.

[31] S. Li, Q. Shi, X. Pang, B. Zhang, and H. Zhang, "Origin of the unusually high dibenzothiophene oils in Tazhong-4 Oilfield of Tarim Basin and its implication in deep petroleum exploration,” Organic Geochemistry, vol. 48, pp. 56-80, 2012.

[32] C. Zhu, H. Yan, L. Yun, Q. Han, and H. Ma, "Characteristics of Cambrian source rocks in well XH1,Shaya Uplift, Tarim Basin," Petroleum Geology \& Experiment, vol. 36, no. 5, pp. 626-632, 2014.

[33] H. Yang, Y. Chen, J. Tian et al., "Great discovery and its significance of ultra-deep oil and gas exploration in well Luntan-1 of the Tarim Basin," China Petroleum Exploration, vol. 25, no. 2, pp. 62-72, 2020.

[34] H. Cui, L. Tian, N. Zhang, and J. Liu, "Nanhua-Sinian rift distribution and its relationship with the development of Lower Cambrian source rocks in the southwest depression of Tarim Basin,” Acta Petrolei Sinica, vol. 37, no. 4, pp. 430-438, 2016.

[35] G. Zhu, H. Yang, B. Zhang et al., "Ultra-long distance migration of hydrocarbon," Acta Petrologica Sinica, vol. 29, no. 9, pp. 3192-3212, 2013.

[36] Q. Zhuo, M. Zhao, Y. Li, and Y. Wang, "Dynamic sealing evolution and hydrocarbon accumulation of evaporite cap rocks: an example from Kuqa foreland basin thrust belt," Acta Petrolei Sinica, vol. 35, no. 5, pp. 847-856, 2014. 